DOI: $10.1515 / \mathrm{rpp}-2016-0016$

$\mathrm{PhD}$ in Philological Sciences, Associate Professor, MARYNA IKONNIKOVA

Khmelnytskyi National University, Ukraine

Address: 11 Instytutska St., Khmelnytskyi, 29016, Ukraine

E-mail: ikonnikova@ukr.net

\title{
MASTER PROGRAM IN FOREIGN LANGUAGE EDUCATION AT NEW YORK UNIVERSITY STEINHARDT (US)
}

\begin{abstract}
The article deals with master program in foreign language education at New York University Steinhardt (US). Thus, its peculiarities have been revealed. It has been defined that the study program presupposes mastering of foreign language teaching approaches that meet various needs of learners. It has been indicated that students acquire the understanding of educational conditions as well as economic, social and cultural factors influencing learning; develop professional knowledge of linguistics, (foreign) language acquisition, (foreign) language pedagogy, etc. The curriculum of the program is based on block-modular and interdisciplinary approaches that results in considerable flexibility. In addition, students have excellent opportunities to gain valuable practical experience and strengthen professional teaching skills during student teaching placements including abroad. It has been concluded that professional training of future specialists in the field of foreign language education on the example of New York University contributes to forming of modern, competitive philologists able to apply the latest teaching technologies, forms and methods to the educational process and adapt to fast-changing conditions of the educational environment. It has been emphasized that the abovementioned positive aspects of US experience in training foreign language teachers can be taken into account while developing national curricula in education, philology, linguistics, applied linguistics etc.

Key words: master program, Master of Arts, foreign language education, New York University Steinhardt, the USA.

\section{INTRODUCTION}

Modern Ukrainian society is actively integrating into open information space of multicultural environment. Native and foreign scholars consider lingual and cultural variety to be one of the most valuable constituents of the world cultural heritage as well as philosophy of intercultural social interaction in multicultural and multilingual space. Moreover, the world variety of lingual communities and cultures in perspective is to become a means of mutual understanding rather than an obstacle for a dialogue between representatives of various cultural backgrounds. Therefore, the professional training of highly qualified specialists capable of communicating in intercultural dimensions is extremely topical in Ukraine nowadays. These are, predominantly, specialists in the field of philology, in particular, foreign language teachers.

Consequently, it is necessary that the adequate system of personal development and professional actualization be developed and successfully implemented. So, native scholars should apply to foreign experience in organizing the educational process with the use of innovative communication and integration technologies, new forms and methods of social and pedagogical practice in various conditions with different categories of learners.
\end{abstract}


In our opinion, the experience of the United States is extremely relevant in the matter as American specialists in the whole range of fields, in particular, foreign language philologists, are highly recognized in the world labour market.

\section{THE AIM OF THE STUDY}

The aim of the study is to reveal peculiarities of master program in Foreign Language Education at New York University Steinhardt (US).

\section{THEORETICAL FRAMEWORK AND RESEARCH METHODS}

The education system of the USA has been actively studied by native scholars, namely, N. Bidyuk (theory and practice in professional training of the unemployed); S. Brudina (professional training of Masters in Education Administration); L. Chorna (practical training of specialists in tourism); V. Korniyenko (professional training of Bachelors of Arts in Applied Linguistics); M. Nagach (professional training of future teachers at professional development schools); I. Pasynkova (professional training of Bachelors of Arts in Foreign Languages); N. Sobchak (professional training of social workers in the system of continuing education); I. Sulim-Karlil (organization of students' individual extracurricular activities at teachers colleges) and many others.

Foreign scholars have also paid attention to the higher education system of the USA and professional training of specialists in a range of fields, in particular, N. Bartels, M. C. Bracken, M. L. Duryea, H. L. Gholz, P. K. Ramachandran Nair, G. W. Shilling, M. Tight, H. de Wit and many others.

It should be mentioned that despite an abundance of scientific and pedagogical literature on professional training of specialists in the USA, master programs in Foreign Language Education at American universities have not been properly studied yet.

During our study we have used such methods as analysis, synthesis, induction, deduction, systematization, generalization, individualization and comparison.

\section{RESULTS}

First of all, it should be mentioned that the content of US higher education is grounded on the principles of fundamentalization, multiculturalism and pragmatism. Second of all, humanitarization of professional education is one of the leading trends of its development. In addition, significant attention is paid to students' specialization. The structuralization of learning content and development of curricula are accomplished on the basis of block-modular and interdisciplinary approaches to their structure (Пасинкова, 2005).

Thus, having analyzed educational offers generated by specialized websites we singled out master programs in Foreign Language Education at New York University Steinhardt (NYU).

Department of Teaching and Learning at NYU develops its programs and courses to achieve such goals:

1) to prepare specialists comprehending various historical forces, philosophical positions and ideologies, difficulties of learning and teaching processes in the multicultural world that is constantly changing thus influencing social, political and technological spheres;

2) to build an educational community with general and detailed understanding of study levels, teachers and students' roles, areas of academic specialization, different cultures while taking into account the peculiarities of diverse backgrounds;

3 ) to build an academic community striving for education system development;

4) to strengthen teachers' interactions with students and field-based specialists;

5) to create support groups that will assist teachers and students as they meet the challenges in teaching;

6) to form educators comprehending the need for changes as well as their roles in achieving them (NYU Steinhardt, 2016). 
MA in Foreign Language Education (Grades 7-12, Initial Certification) is designed for those striving for teaching French, Italian, Spanish, Chinese and Japanese at secondary schools both locally and abroad. In general, the program implies studying language acquisition and pedagogy as well as provides students with the opportunity to obtain valuable practical experience due to teaching placements in schools.

Thus, MA in Foreign Language Education consists of core courses, electives, fieldwork and student teaching.

Students are to study a foreign language and linguistics, second language acquisition, teaching methods and technologies, research methodology. In addition, interand multicultural education perspectives, aspects of teaching students with special needs as well as adult learners are taught.

Elective courses provide for language evaluation/assessment and workshops in a foreign language teaching.

Concerning the mode of study, the program is rather flexible. It can be full-time and part-time. The degree can be completed in four semesters. An accelerated full-time basis training of a little more than a calendar year is possible, too. Students can also choose to engage into additional coursework to extend their teaching certification to include grades K-6 (an abbreviation for the grades in school from kindergarten through sixth grade) (NYU Steinhardt, 2016; Your Dictionary, 2016).

We have also analyzed curriculum and degree requirements of the program studied. Thus, in first fall semester students are to gain 12 points. First of all, they are to choose between Applied Linguistic in Chinese, Advanced French for Teachers of French, Applied Linguistics in Spanish, A Target Foreign Language Course at the Graduate School of Arts and Sciences (GSAS) (3-4 points each); Linguistic Analysis; Inquiries into Teaching and Learning (3 points); Teaching Foreign or Second Languages (Theory and Practice) (3 points each); Child Abuse Identification and School Violence Prevention/Drug and Alcohol Education/The Social Responsibilities of Teachers; Field Work in Schools and Other Education Settings (NYU Steinhardt, 2016).

During first spring semester the required number of points is 13. Students are to master Adolescent Learners in Urban Context (2 points); The Second Language Classroom (4 points); one of the following: Intercultural Perspectives in Multilingual Multicultural Education (study abroad option); Bilingual Multicultural Education (3 points each); one of the following: Workshop in Integrating Educational Technology in Teaching and Learning, Foreign Language Education; one of the following: Spanish Syntax for Teachers, Applied Linguistics in French, Advanced Spanish for Teachers of Spanish, Advanced Chinese for Teachers of Chinese, A Target Foreign Language Course at the Graduate School of Arts and Sciences (GSAS) (3-4 points each) (NYU Steinhardt, 2016).

Second fall semester provides for gaining 12 points. Students have the opportunity to participate in either Student Teaching Seminar in Foreign Language Education (grade 7-9) or Student Teaching Seminar in Foreign Language Education (grade 10-12); master Multilingual Multicultural Studies (elective course - 3 points); Second Language Acquisition: Theory and Research (3 points); one of the following: Adolescent Settings, Bilingual Exceptional Children/Educating Students with Special Needs in Middle Childhood (3 points each) (NYU Steinhardt, 2016).

Second spring semester requires only 7 points and consists of such activities: Student Teaching Seminar: Foreign Language Education 7-12 (3 points); one of the following: Integrating Educational Technology in Teaching and Learning, Workshop in Foreign Language 
Education (1 point each); one of the following: Culminating Seminar in Multicultural Multilingual Studies, Advanced Individual Project (3 points each) (NYU Steinhardt, 2016).

It should be noted that graduates must obtain New York State teacher certification if they want to work at a New York City Department of Education (NYCDOE) school. Moreover, students enrolled in a New York State teacher study programs must prove their good standing and receive a certificate before starting teaching when they submit an application to the NYCDOE. Initial certificate, in its turn, is the entry-level teaching certificate for anyone who has completed a New York State teacher preparation program or equivalent coursework. It is valid only for five years, though (NYC Department of Education, 2016).

MA in Foreign Language Education (Grades 7-12, Initial Certification) leads to New York State foreign language teacher certificate. All students must pass the following examinations before graduation to be eligible for NY State teacher certificate. Target foreign language proficiency consists of 30 units of study of the target foreign language on the college level or officially recognized equivalent. Final assessments are Liberal Arts and Sciences Test (LAST); Assessment of Teaching Skills Written (Secondary ATS-W); Content Specialty Test in Target Language (CST).

As it was mentioned above, students are to be engaged into teaching placements, i.e. to complete two-semester student teaching of foreign language in two different New York City schools and grade levels while simultaneously taking a student teaching seminar. In our opinion, this is a great opportunity to integrate theory, subject content and practice. Teachers of the NYU faculty, in their turn, are to offer feedback and guidance as students develop their teaching style and techniques.

Graduates are encouraged to involve into a strong, supportive learning community that presents an additive vision of foreign language and culture acquisition. The members of the faculty are the recognized leaders in the field and are always ready to assist to students both through the courses they teach as well as through individual counseling.

Future foreign teachers have the opportunity to study the interrelationship among language, culture and learning from an intercultural perspective in such countries as China, Hong Kong and the Dominican Republic or they can just participate in other NYU Steinhardt global study programs.

As scientific searches have shown graduates have perfect career opportunities and may hold various positions (see Figure 1) (NYU Steinhardt, 2016).

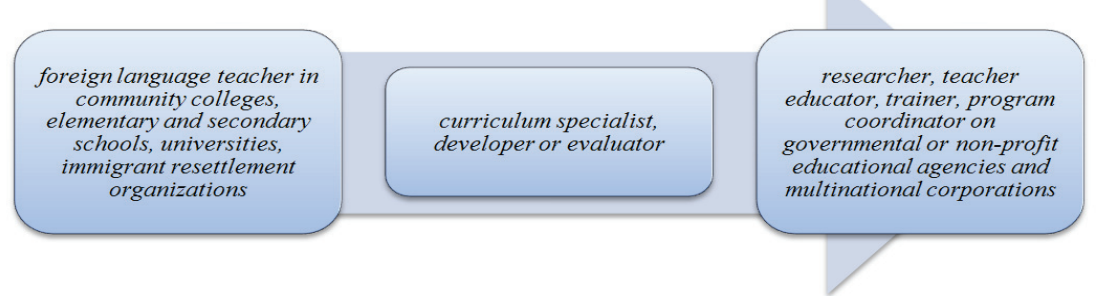

Fig. 1. Positions Held by Graduates in Foreign Language Education Master Program

\section{CONCLUSIONS}

Master program in Foreign Language Education at New York University Steinhardt presupposes mastering of foreign language teaching approaches that meet various educational, linguistic, ethnic needs of the learners. Students acquire the understanding of educational conditions as well as economic, social and cultural factors influencing 
learning; develop professional knowledge of linguistics, (foreign) language acquisition, (foreign) language pedagogy, etc. The curriculum of the program is based on blockmodular and interdisciplinary approaches that results in considerable flexibility. In addition, students have excellent opportunities to gain valuable practical experience and strengthen professional teaching skills during student teaching placements including abroad.

Thus, professional training of future specialists in the field of foreign language education on the example of New York University contributes to forming of modern, competitive philologists able to apply latest teaching technologies, forms and methods to the educational process and adapt to fast-changing conditions of the educational environment.

So, the abovementioned positive aspects of US experience in training foreign language teachers can be taken into account while developing national curricula in education, philology, linguistics, applied linguistics etc.

Rather perspective for further studies we consider detailed analysis of study programs in philology at universities of leading European countries.

\section{REFERENCES}

1. NYC Department of Education. (2016). New York State Certification. Retrieved 22.05.2016 from : http://teachnyc.net/certification/new-york-state-certification.

2. NYU Steinhardt. (2016). MA in Foreign Language Education, Grades 7-12, Initial Certification. Retrieved 22.05.2016 from : http://steinhardt.nyu.edu/teachlearn/foreign/ ma/initial.

3. NYU Steinhardt. (2016). MA in Foreign Language Education: Programs of Study. Retrieved 22.05.2016 from : http://steinhardt.nyu.edu/teachlearn/foreign/ma/ program of study\#initial.

4. Your Dictionary. (2016). K-6. Retrieved 22.05.2016 from : http://www.yourdictionary.com/k6.

5. Пасинкова, I. (2005). Система підготовки бакалаврів гуманітарних наук $з$ іноземної мови в університетах США [The System of Bachelors of Arts' in Foreign Language Training at Universities of the USA]. Abstract of Thesis for PhD. Київ : Інститут вищої освіти академії педагогічних наук України, 22 р. (in Ukrainian). 